\title{
PENGARUH KOORDINASI TERHADAP EFEKTIVITAS KERJA PEGAWAI PADA SEKRETARIAT DAERAH KOTA KENDARI
}

\author{
${ }^{1}$ Bakti, ${ }^{2}$ Muhammad Yusuf, ${ }^{3}$ La Ode Aslim \\ 1,2,3 Fakultas IImu Sosial dan IImu Politik, Universitas Halu Oleo \\ Bakti.pascasarjana@gmail.com, myusuf@gmail.com, laodeaslim@gmail.com \\ Kendari - Indonesia
}

\begin{abstract}
This study aims to determine the extent of the influence of coordination on employee work effectiveness at the Regional Secretariat of Kendari City. By using questionnaire data collection techniques, documentation and interviews with informants who are considered potential to provide information about the coordination system and work effectiveness at the Kendari City Regional Secretariat.

Then to test the hypothesis, statistical analysis techniques are used through simple linear regression, which is to find out the relationship between the independent variables $(X)$, namely coordination and non-independent variables $(Y)$, namely the effectiveness of employees in Kendari City. Testing the hypothesis is used version 22 of the Statistics Package for Social Science (SPSS) program. The results of this study indicate that coordination has a significant influence on the effectiveness of Employee Work in the Regional Secretariat of Kendari City. The results of testing the Spearman-Brown Correlation coefficient indicate that coordination has a relatively large contribution to work effectively in the Regional Secretariat of Kendari City. This means that the better the coordination is carried out, the higher the work effectiveness of employees. In this study, it was also found that the implementation of the main tasks and functions of the ten sections and twenty-nine sub-sections had not been implemented properly.
\end{abstract}

Keywords: Coordination; Effectiveness; Work

\begin{abstract}
Abstrak
Penelitian ini bertujuan untuk mengetahui sejauhmana pengaruh koordinasi terhadap efektivitas kerja pegawai pada Sekretariat Daerah Kota Kendari. Dengan menggunakan tekhnik pengumpulan data kuesioner, dokumentasi dan wawancara dengan informan yang dianggap berpotensi untuk memberikan informasi tentang system koordinasi serta efektifvitas kerja pada Sekretariat Daerah Kota Kendari.

Selajutnya untuk menguji hipotesis yang dikemukakan, maka digunakan teknik analisis statistik melalui Regresi linier sederhana yakni untuk mengetahui bentuk hubungan pengaruh antara variabel Bebas (X) yaitu Koordinasi dan variabel tak bebas (Y) yaitu Efektivitas kerja pegawai di Kota Kendari. Pengujian hipotesis digunakan program Statistics Package for Social Science (SPSS) versi 22. Hasil Penelitian ini menunjukkan bahwa koordinasi berpengaruh secara signifikan terhadap efektivitas Kerja Pegawai di Sekretariat Daerah Kota Kendari. Hasil pengujian koefisien Korelasi Spearman-Brown menunjukkan bahwa koordinasi mempunyai sumbangan yang relatif besar terhadap efektivitas kerja di Sekretariat Daerah Kota Kendari. Artinya semakin baik koordinasi dilaksanakan maka efektivitas kerja pegawai semakin tinggi. Dalam penelitian ini juga ditemukan bahwa pelaksanaan tupoksi dari sepuluh bagian dan dua puluh sembilan sub bagian belum dilaksanakan dengan baik.
\end{abstract}

\section{Kata Kunci: Efektivitas; Kerja; Koordinasi}




\section{PENDAHULUAN}

Keberadaan organisasi sangat diperlukan, karena organisasi merupakan bagian dari kehidupan manusia. Davis dan Newstrom dalam (Agus Dharma, 2004) berpendapat, bahwa, Organisasi tidak berdiri sendiri, ia merupakan dari sistim yang lebih besar yang memuat banyak unsur lain, seperti pemerintah, keluarga, dan organisasi lainnya. Organisasi yang belum memiliki tingkat efektivitas yamg tinggi memungkinkan organisasi tidak dapat menghasilkan out put yang kompetitif, dipihak lain tingkat efektivitas yang rendah akan mengakibatkan organisasi sulit bersaing dengan organisasi lainnya dan akibatnya masyarakat kurang menghargai keberadaannya.

Tjokrowinoto, (1996), mengemukakan bahwa untuk mencapai tujuan pembangunan daerah secara efektif dan efisien, diperlukan aparatur daerah yang berkemampuan, disiplin berdedikasi, tinggi, handal dan profesional, mampu mengatasi setiap permasalahan seiring dengan perkembangan yang trend. Untuk menghindarai masalah-masalah yang ada dan mungkin timbul diperlukan cara-cara yang baru, yang didasarkan ilmu pengetahuan dan dibarengi penggunaan alat-alat tehnik yang dapat memudahkan pencapaian hasil secara lebih efisien dan efektif. Percepatan perkembangan global perlu dilakukan penyempurnaan untuk menjawab tantangan yang dihadapi terutama kesiapan Sumber Daya Manusia (SDM) aparatur yang berkualitas dan bermoral.

Organisasi dan koordinasi tidak dapat dipisahkan. Koordinasi berfungsi sangat penting bagi organisasi, apalagi organisasi itu harus berjalan sebagai suatu sistem. Karena organisasi itu harus berjalan sebagai suatu sistem, maka bagian-bagian atau unit-unit yang ada di dalam suatu organisasi harus berjalan sebagai suatu sistem pula, walaupun setiap unit mempunyai tugas dan sasaran tersendiri, namun tiap-tiap unit atau bagian-bagian tidak dapat melepaskan diri dari unit atau bagian yang lainnya. Oleh sebab itu, suatu unit tidak dapat berfungsi dengan baik tanpa dibantu dengan unit lainnya, atau antara unit terjadi interdependensi. Untuk itulah koordinasi sangat diperlukan dalam suatu organisasi, yang dapat menjadi penghubung untuk kepentingan keberhasilan suatu tujuan yang telah ditetapkan.

Pelaksanaan koordinasi diperlukan pembinaan sumber daya manusia agar kegiatan yang berhubungan dengan masing-masing bidang dapat berlangsung secara efektif dan efisien, dalam rangka memulihkan citra dan kewibawaan aparatur pemerintah. Hal ini disebabkan karena adanya perbedaan-perbedaan seperti satuan pekerjaan, kapasitas individu atau pejabat atau karakteristik lainnya yang dapat mempengaruhi sikap dan perilaku setiap pelaksana dalam suatu organisasi.

Pemerintah Kota Kendari sebagai sebuah organisasi telah melakukan upaya-upaya perbaikan dalam meningkatkan kinerja dan memberikan pelayanan publik sebagai bagian 
dari tugas dan fungsi pemerintah. Berkaitan dengan itu, Walikota Kendari telah melahirkan Peraturan Pemerintah Kota Kendari Nomor 5 Tahun 2016 tentang pembentukan dan susunan perangkat daerah kota kendari. Selanjutnya dijabarkan melalui pembidangan sesuai yang dibebankan kepada masing-masing bagian dan sub bagian.

Masing-masing bagian dan sub bagian mempunyai tupoksi yang berbeda, namun terkoordinasi oleh Asisten dan Sekretaris Daerah. Dalam pelaksanaan tugas dan fungsi, jika terjadi keterlambatan di satu atau beberapa sub bagian akan mempengaruhi efektivitas kinerja organisasi.

Berdasarkan hasil pengamatan yang dilakukan dilapangan, bahwa dalam pelaksanaannya terdapat beberapa masalah adalah : (1) Tugas pokok dan fungsi masing-masing bagian sering dilaksanakan tidak sesuai dengan rencana yang ditentukan, (2) Pekerjaan kantor tidak efektif karena pegawainya banyak membuang waktu, diantaranya terlalu banyak meninggalkan pekerjaan dengan alasan istirahat atau melakukan kegiatan-kegiatan diluar tugas pokoknya, (3) Adanya tugas tambahan dari masing-masing staf untuk melaksanakan pekerjaan di luar tugas pokok dan fungsinya, seperti kerja bakti, menyebabkan koordinasi antar bagian dan sub bagian tidak dapat berjalan degan baik karena alasan sedang berada di luar kantor. Keadaan ini menyebabkan pelayanan administrasi publik dan administrasi kepegawaian tidak bisa berjalan sesuai target waktu yang telah di tetapkan. Berbagai keterlambatan urusan dan pelayanan administrasi publik, administrasi kepegawaian yang ditemukan, salah satunya disebabkan oleh faktor koordinasi antar bagian dan sub bagian.

Berdasarkan uraian yang telah dijelaskan dalam latar belakang penelitian, maka masalah yang dikemukakan dalam penelitian ini adalah Apakah Koordinasi berpengaruh terhadap Efektivitas Kerja Pegawai di Sekretariat Daerah Kota Kendari ? Seberapa besar Pengaruh Koordinasi terhadap Efektivitas Kerja Pegawai di Sekretariat Daerah Kota Kendari ?

Untuk memberikan pemahaman yang sama terkait kajian "Pengaruh Koordinasi terhadap Efektivitas Kerja Pegawai di Sekretariat Daerah Kota Kendari, maka berikut disajikan beberapa konsep yang subtansi dari penelitian ini.

\section{Konsep dan Teori Koordinasi}

Pengertian koordinasi menurut Stoner (2012) adalah "Proses penyatupaduan sasaran-sasaran dan kegiatan-kegiatan dari unit-unit yang terpisah (departemen atau bidang-bidang fungsional) dalam suatu organisasi secara efisien". Sedangkan Bernard mendefinisikan "organisasi sebagai sebuah sistem yang memaksakan koordinasi kerja sama antara dua orang atau lebih" (Simamora, 2015).

Selanjutnya menurut Ismail Solihin (2009), megatakan bahwa karateristik pertama dari organisasi adalah adanya koordinasi upaya dari sumber daya manusia yang terlibat dalam 
organisasi. Penggabungan yang terkoordinasi dengan baik akan menghasilkan sesuatu yang jauh lebih baik dibandingkan upaya perseorangan.

Sementara itu Hasibuan (2009) berpendapat bahwa : "koordinasi merupakan kegiatan mengarahkan, mengintegrasikan, dan mengkoordinasikan unsur-unsur manajemen dan pekerjaan-pekerjaan para bawahan dalam mencapai tujuan organisasi".

Sejalan dengan pendapat Yohanes Yahya (2006), mengatakan bahwa koordinasi merupakan proses pengintegrasian tujuan dan kegiatan pada satuan yang terpisah pada suatu organisasi untuk mencapai tujuan organisasi secara efisien.

Menurut G.R Terry dalam Hasibuan (2016) berpendapat bahwa koordinasi adalah suatu usaha yang sinkron dan teratur untuk menyediakan jumlah dan waktu yang tepat, dan mengarahkan pelaksanaan untuk menghasilkan suatu tindakan yang seragam dan harmonis pada sasaran yang telah ditentukan.

Sementara Manullang (2014) melihat koordinasi sebagai usaha mengarahkan kegiatan seluruh unit-unit organisasi agar tertuju untuk memberikan sumbangan semaksimal mungkin untuk mencapai tujuan organisasi secara keseluruhan dengan adanya koordinasi akan terdapat keselarasan aktivitas diantara unit-unit organisasi dalam mencapai tujuan organisasi. Sedangkan Richard L. Daft (2014) koordinasi (coordination) mengacu pada kualitas kolaborasi di antara departemen.

Pandangan Manulang (2014) sejalan dengan pandangan Hodgetts (1982) "Pengorganisasian merupakan fungsi menajerial yang diperlukan untuk menyatupadukan serta mengharmoniskan dalam pencapaian tujuan organisasi". Demikian pula Barnes et al. (1984) mengatakan bahwa. "Organisasi sebagai "pembagian kerja" diantara orang-orang yang usahanya harus "di koordinasikan" untuk mendapat sasaran".

Baik pendapat Manullang, Hodgetts maupun pendapat Barnes et al. pada dasarnya menekankan bahwa pentingnya fungsi koordinasi bagi suatu organisasi. Dengan organisasi maka akan muncul pembagian kerja, dengan pembagian kerja memang dapat memecahkan masalah ketidak mampuan seorang manajer dalam pelaksanaan kerja, tetapi dari situ timbul masalah lain, yaitu koordinasi kegiatan-kegiatan orang yang memperoleh bagian kerja demi tercapainya sasaran atau tujuan organisasi. Agar tidak terjadi kesimpangsiuran atau duplikasi kegiatan dalam suatu organisasi maka diperlukan koordinasi. Karena itu menurut Barnes et al. (2000) perlu diperhatikan dalam pelaksanaan koordinasi, bahwa "Prasyarat penting untuk koordinasi adalah keterlibatan semua orang dalam bekerja dengan sasaran yang tepat, dan dalam kesadaran mereka akan nilai sumbangan yang mereka berikan, kemudian syarat pokok selanjutnya adalah komunikasi yang baik".

Bila diperhatikan pendapat-pendapat baik tentang organisasi maupun tentang koordinasi di atas, maka dapat disimpulkan bahwa koordinasi bertujuan menciptakan efisiensi serta 
efektivitas pelaksanan tugas atau pekerjaan dalam mencapai sasaran atau tujuan organisasi yang telah ditetapkan sebelumnya.

Oleh karena itu maka bagi suatu organisasi baik pemerintahan maupun bagi organisasi sosial kemasyarakatan, koordinasi itu semakin penting artinya. Koordinasi dimaksudkan harus di arahkan pada kegiatan-kegiatan untuk pencapaian tujuan.

Oleh karena itulah menurut Simon (1982), mengungkapkan bahwa "Kefektifan seorang individu dalam mencapai sasarannya di dalam setiap situasi sosial akan tergantung tidak saja pada kegiatannya, tetapi juga pada bagaimana itu berhubungan dengan apa yang sedang dikerjakan oleh individu-individu yang bersangkutan lainnya".

\section{Konsep dan Teori Efektivitas}

Menurut (Westra, et al. 1985) bahwa efektivitas adalah "Suatu keadaan yang mengandung pengertian terjadinya sesuatu efek atau akibat yang dikehendaki. Kalau seseorang melakukan suatu perbuatan dengan maksud tertentu yang memang dikehendaki, maka orang itu dikatakan efektif kalau menimbulkan akibat sebagaimana yang dikehendakinya".

Kemudian Stoner, (2012) mengemukakan bahwa efektivitas ialah kemampuan untuk menentukan tujuan yang memadai : "melakukan hal yang tepat". Sedangkan Steers, (1985), berpendapat bahwa batu uji yang sebenarnya untuk manajemen yang baik adalah "kemampuan mengorganisasi dan memanfaatkan sumber daya yang tersedia dalam tugas untuk mencapai dan memelihara suatu tingkat operasi yang efektif". Kata kunci pengertian ini ialah kata efektif karena pada akhirnya keberhasilan kepemimpinan dan organisasi diukur dengan konsep efektivitas itu. Walaupun banyak orang yang setuju bahwa manajemen memegang peranan utama dalam mencapai efektivitas organisasi, tetapi sulit memerinci apa yang dimaksud dengan konsep efektivitas itu sendiri.

Ndraha, (2012) mengemukakan tentang efektivitas yaitu: Efektivitas lebih menitikberatkan pada hasil yang dimulai dari adanya tujuan organisasi. Efektivitas juga dapat diartikan sebagai tingkat keberhasilan dalam mencapai target yang ditetapkan. Tujuan dalam organisasi pemerintahan terdiri atas tujuan jangka panjang yang bersifat abstrak, sehingga perlu dioperasionalkan melalui sektor-sektor yang lebih konkret. Hal ini dapat ditemukan dalam Repelita, selanjutnya dioperasionalkan lagi melalui target, sehingga mudah diukur.

\section{Kerangka Pemikiran}

Setiap bentuk organisasi tidak dapat melepaskan diri dari kegiatan koordinasi, karena koodinasi merupakan salah satu prinsip unsur kegiatan esensial organisasi, salah satu fungsi manajemen dan salah satu unsur dinamik administrasi. Karena itulah koordinasi dikelompokan ke dalam salah satu fungsi organik, yaitu fungsi yang mutlak harus dijalankan oleh administrasi dan manajemen. 
Organisasi dapat dilihat dari sudut vertikal dan horizontal, begitu juga koordinasi dapat bersifat vertikal dan horizontal. Koordinasi bersifat vertikal terjadi apabila ada hubungan antara atasan dan bawahan; koordinasi bersifat horizontal terjadi antara karyawan dengan karyawan yang lain dalam suatu tingkatan. Begitu pentingnya koordinasi dalam suatu organisasi sehingga para alhi administrasi menempatkan sebagai titik pusat analisisnya.

Pengertian koordinasi telah dijelaskan para pakar bahwa koordinasi bertujuan menciptakan efisiensi dan efektivitas pelaksanaan tugas atau pekerjaan dalam mencapai sasaran atau tujuan organisasi yang telah ditetapkan sebelumnya. Demikian halnya mengenai pentingnya koordinasi dilakukan dalam organisasi telah dijelaskan oleh Hasibuan (2016) dan Manullang (2014). Stoner (2012) mengembangkan dalam pendekatan komunikasi bahwa koordinasi merupakan faktor komunikasi dalam organisasi.

Berbagai pembahasan mengenai koordinasi, tampaknya terdapat kesamaan pandangan tentang koordinasi. Intinya koordinasi merupakan proses menyatukan aktivitas dari berbagai unit organisasi untuk mencapai tujuan dan dilaksanakan secara efektif dan efisien, dalam upaya mempertahankan serta mengembangkan eksistensi organisasi. Koordinasi juga dimaksudkan untuk menghindarkan kecenderungan pemisahan badan, intansi atau unit yang dibentuk berdasarkan pembagian tugas atau fungsi dan tanggung jawab sebagi konsekuensi berorganisasi dan bekerja sama.

Berdasarkan uraian tersebut di atas, maka kerangka pemikiran dalam penelitian ini di jelaskan pada Gambar 1.

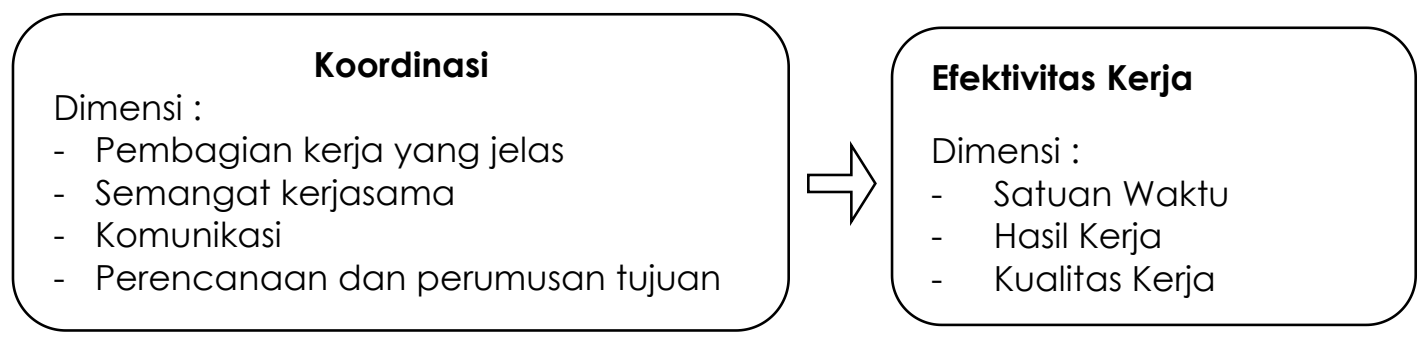

\section{Hipotesis Penelitian}

Gambar 1. Kerangka Pemikiran

Berdasarkan identifikasi masalah dan kerangka pemikiran sebelumnya, maka peneliti mengemukakan hipotesis sebagai berikut :

1. Koordinasi berpengaruh terhadap Efektivitas Kerja Pegawai di Sekretariat Daerah Kota Kendari;

2. Koordinasi berpengaruh besar terhadap Efektivitas Kerja Pegawai di Sekretariat Daerah Kota Kendari

\section{METODOLOGI}

\section{Desain Penelitian}

Penelitian ini menggunakan metode survey eksplanatori. Untuk melengkapi data utama (data primer) juga digunakan wawancara terhadap pimpinan bagian dan sub bagian untuk 
Open Access at: http://ojs.uho.ac.id/index.php/PUBLICUHO/index

memperkuat dan mendalami faktor-faktor yang tidak dapat (belum) terungkap dalam kuesioner. Selain itu dilakukan observasi sebagai pelengkap dari metode survey.

\section{Variabel Penelitian dan Operasionalisasi Variabel}

Variabel yang diteliti dalam penelitian ini terdiri dari 2 (dua) variabal yaitu:

$\rightarrow$ Koordinasi $(X)$, sebagai variabel bebas (independent variables)

$\rightarrow$ Efektivitas kerja (Y) sebagai Variabel tak bebas (dependent variables).

1) Koordinasi adalah usaha menyatukan aktivitas untuk saling komunikasi dari berbagai unit dalam lingkup Sekretariat Kota Kendari untuk mencapai tujuan yang telah ditetapkan. Koordinasi mempunyai empat dimensi yaitu : (1) dimensi pembagian kerja yang jelas, (2) semangat kerja sama, (3) komunikasi, (4) perencanaan dan perumusan tujuan. Penjelasan masing-masing dimensi adalah :

$\rightarrow$ Pembagian kerja yang jelas adalah adanya pembagian tupoksi yang jelas antara bagian dan sub bagian dalam lingkup Sekretariat Kota Kendari.

$\rightarrow$ Semangat kerja sama adalah usaha saling membantu dan memberi dukungan dalam setiap kegiatan antar bagian dan sub bagian lingkup Sekretariat Kota Kendari.

$\rightarrow$ Komunikasi adalah adanya saling memberi informasi secara horisontal maupun vertikal antar bagian dan sub bagian dalam lingkup Sekretariat Kota Kendari.

$\rightarrow$ Perencanaan dan perumusan tujuan adalah adanya rencana kerja dan rumusan tujuan yang ingin dicapai dari setiap bagian dan sub bagian dalam lingkup Sekretariat Kota Kendari.

2) Efektivitas kerja adalah penyelesaian pekerjaan tepat pada waktunya yang telah ditentukan. Dimensi-dimensi efektivitas adalah : satuan waktu, satuan hasil, dan kualitas kerja. Penjelasan masing-masing dimensi efektivitas adalah :

$\rightarrow$ Satuan waktu adalah lamanya waktu yang digunakan untuk melakukan koordinasi dan menyelesaikan suatu pekerjaan

$\rightarrow$ Satuan hasil adalah jumlah dan jenis pekerjaan yang dapat diselesaikan dalam suatu kurun waktu

$\rightarrow$ Kualitas kerja adalah tingkat ketercapaian hasil suatu pekerjaan dengan baik dan memenuhi standar yang telah ditentukan.

\section{Populasi, Sampel dan Metode Penarikan Sampel}

Populasi penelitian ini adalah sekretariat Daerah Kota Kendari yakni keseluruhan staf dan pimpinan yang berada di Sekretariat Daerah Kota Kendari, sebanyak 202 orang.

Dari populasi tersebut diambil sampel sebanyak 66 orang dengan teknik Stratified Random Sampling. Untuk memperkuat informasi tentang pelaksanaan koordinasi maka diambil 5 orang informan yaitu (1) Asisten Administrasi Umum, (2) Kepala Bagian dua orang, dan (3) Kepala Sub Bagian 2 orang. 


\section{Prosedur Pengumpulan Data}

Pengumpulan data dilakukan dengan beberapa cara:

1. Cara kuesioner dilakukan untuk mendapatkan data mengenai Koordinasi antar bagian, serta data tentang efektivitas kerja.

2. Cara dokumenter dilakukan untuk mendapatkan data jumlah pegawai, banyaknya kegiatan antar bagian dan sub bagian, dan tugas pokok dan fungsi (tupoksi) dari masing-masing bagian dan sub bagian.

3. Cara wawancara dilakukan untuk mengungkap hal-hal yang tidak mampu diungkap melalui cara kueioner dan dokumenter.

\section{Teknik Analisis Data}

Untuk menguji hipotesis yang telah dikemukakan, digunakan teknik analisis statistik melalui Regresi linier sederhana yaitu untuk mengetahui bentuk hubungan pengaruh antara variabel Bebas (X) yaitu Koordinasi dan variabel tak bebas (Y) yaitu Efektivitas kerja pegawai di Kota Kendari Provinsi sulawesi Tenggara. Pengujian hipotesis digunakan program Statistics Package for Social Science (SPSS) versi 22.

\section{HASIL DAN PEMBAHASAN}

\section{A. Analisis Data Penelitian}

1. Koordinasi pegawai sekretariat Daerah Kota Kendari sebagai variabel bebas (X) yaitu, menentukan fungsi-fungsi, tugas-tugas dan kegiatan-kegiatan/pekerjaanpekerjaan apa yang akan dilakukan untuk mencapai tujuan tersebut, adapun dimensinya adalah (1) Aspek pembagian kerja yang jelas, (2) semangat kerjasama, (3) komunikasi, (4) perencanaan dan perumusan tujuan. Untuk lebih jelasnya, diuraikan perdimensi sesuai hasil penelitian.

a. Pembagian kerja yang jelas, yaitu menentukan fungsi-fungsi, tugas-tugas dan kegiatan-kegiatan/pekerjaan-pekerjaan serta membagi pekerjaan tersebut sesuai dengan bidang dan tugas secara merata untuk mencapai tujuan suatu organisasi. indikatornya adalah rincian aktivitas tertulis secara jelas, keterkaitan antara unit kerja yang sejenis.

Dari hasil penelitian, dimensi pembagian kerja yang jelas dinyatakan oleh responden dapat dilihat pada Tabel 1.

Tabel 1. Distribusi Frekuensi Jawaban Responden Dimensi Pembagia Kerja

\begin{tabular}{|c|c|c|c|}
\hline No. & Jawaban Responden & Frekuensi & Persentase \\
\hline 1. & Sangat Setuju & 16 & 25.00 \\
\hline 2. & Setuju & 35 & 51.32 \\
\hline 3. & Ragu-ragu & 15 & 23.68 \\
\hline 4. & Tidak Setuju & 0 & 0,00 \\
\hline \multirow[t]{2}{*}{5.} & Sangat Tidak Setuju & 0 & 0,00 \\
\hline & $J \cup m / a h$ & 66 & 100,00 \\
\hline
\end{tabular}

Sumber : Data diolah, 2019 
Dari data pada tabel 1, terlihat bahwa responden yang memberikan pernyataan sangat setuju yaitu sebanyak 16 orang yang berarti 25.00 persen yang menyatakan bahwa pembagian kerja sangat berpengaruh terhadap efektivitas kerja di Kota Kendari. Kemudian 35 responden yang menyatakan setuju yang berarti 51.32 persen responden yang mendukung pembagian kerja berpengaruh terhadap efektivitas kerja di Kota Kendari, dan 15 orang responden atau 23.68 persen, yang ragu-ragu tentang pengaruh pembagian kerja terhadap efektivitas kerja di Sekretariat Kota Kendari.

b. Semangat kerjasama yaitu apakah setiap bidang yang ada telah sesuai dengan kebutuhan. indikatornya adalah kesediaan petugas bekerjasama dengan pimpinan dan sesama petugas, kesediaan saling bantu antara petugas sehubungan dengan tugasnya, dimensi semangat kerjasama yang dinyatakan oleh responden di lihat pada Tabel 2.

Tabel 2. Distribusi Frekunsi Jawaban Responden Dimensi Semangat Kerjasama

\begin{tabular}{|c|c|c|c|}
\hline No. & Jawaban Responden & Frekuensi & Persentase \\
\hline 1. & Sangat Setuju & 13 & 21.05 \\
\hline 2. & Setuju & 34 & 50.00 \\
\hline 3. & Ragu-ragu & 19 & 28.95 \\
\hline 4. & Tidak Setuju & 0 & 0,00 \\
\hline 5. & Sangat Tidak Setuju & 0 & 0,00 \\
\hline & Jumlah & 66 & 100,00 \\
\hline
\end{tabular}

Dari Tabel 2, terlihat bahwa 13 responden atau 21.05\% reponden yang menyatakan sangat setuju dan 34 responden atau 50.00 persen yang menyatakan setuju, bila semangat kerjasama sangat berpengaruh terhadap efektivitas kerja di Sekretariat Kota Kendari, kemudian 19 responden atau $28.95 \%$ yang tidak berpendapat tentang pengaruh semangat kerjasama pada pegawai sekretariat Kota Kendari terhadap efektivitas kerja di Sekretariat Kota Kendari.

c. Komunikasi, yaitu mengingat kemampuan seorang pimpinan terbatas, maka perlu pertimbangan mengenai jumlah pegawai dalam suatu bidang. Prinsip komunikasi berkaitan dengan jumlah bawahan yang dapat dikendalikan secara efektif oleh seorang manajer atau atasan. Pentingnya komunikasi langsung dalam suatu lingkungan kerja dapat mencegah terjadinya kesalahan informasi dalam menjalankan tugasnya, juga bawahan dapat secara langsung memberikan laporan kepada seorang manajer tertentu. Indikatornya adalah komunikasi vertikal, komunikasi horisontal. Dari hasil penelitian, dimensi komunikasi yang dinyatakan oleh responden dapat dilihat pada Tabel 3. 
Tabel 3 : Distribusi Frekuensi Jawaban Responden Dimensi Komunikasi

\begin{tabular}{rlrr}
\hline No. & Jawaban Responden & Frekuensi & Persentase \\
\hline 1. & Sangat Setuju & 16 & 25.00 \\
2. & Setuju & 29 & 43.42 \\
3. & Ragu-ragu & 21 & 31.58 \\
4. & Tidak Setuju & 0 & 0,00 \\
5. & Sangat Tidak Setuju & 0 & 0,00 \\
\hline & Jum I a h & 66 & 100,00 \\
\hline
\end{tabular}

Sumber : Data diolah, 2019

Dari Tabel 3, terlihat bahwa yang menyatakan sangat setuju 16 responden atau 25.00 persen, yang menyatakan sangat setuju, dan 29 responden atau 43.42 persen yang menyatakan setuju bahwa komunikasi bepengaruh secara positif terhadap efektivitas kerja di Sekretariat Kota Kendari, serta sebanyak 21 responden atau 31.58\%. yang tidak berpendapat atau raguragu untuk menyatakan tentang pengaruh komunikasi terhadap efektivitas kerja di Sekretariat Kota Kendari.

d. Perencanaan dan perumusan tujuan, yaitu informasi tugas pekerjaan haruslah selalu diikuti dengan seksama sehingga setiap kegiatan/pekerjaan yang diberikan tidak salah dalam pelaksanaannya, indikatornya adalah perumusan tujuan dengan jelas, tercapainya konsekuensi dari tujuan yang dirumuskan. Dari hasil penelitian, dimensi perencanaan dan perumusan tujuan dengan jelas yang dinyatakan oleh responden dapat dilihat pada Tabel 4.

Tabel 4. Distribusi Frekuensi Jawaban Responden Dimensi Perencanaan dan Perumusan Tujuan

\begin{tabular}{clcc}
\hline No. & Jawaban Responden & Frekuensi & Persentase \\
\hline 1. & Sangat Setuju & 14 & 22.37 \\
2. & Setuju & 28 & 42.11 \\
3. & Ragu-ragu & 24 & 35.53 \\
4. & Tidak Setuju & 0 & 0,00 \\
5. & Sangat Tidak Setuju & 0 & 0,00 \\
\hline \multicolumn{2}{l}{ Jum I a h } & 66 & 100,00 \\
\hline
\end{tabular}

Sumber : Data diolah, 2019

Dari Tabel 4, terlihat bahwa 14 responden atau $22.37 \%$, yang menyatakan sangat setuju, dan 28 responden atau $42.11 \%$ yang menyatakan setuju, tentang perencanaan dan perumusan tujuan pada pegawai efektivitas kerja di Sekretariat Kota Kendari. kemudian 24 responden atau 35.53 persen, yang tidak berpendapat, tentang pernyataan bahwa perencanaan dan perumusan tujuan berpengaruh positif terhadap efektivitas kerja di Sekretariat Kota Kendari.

2. Efektivitas Kerja Pegawai Sekretariat Daerah Kota Kendari, sebagai Variabel Bebas (Y) : yaitu kondisi yang dapat menjelaskan data mengenai efektivitas kerja pegawai di secretariat daerah Kota Kendari, dengan dimensinya yaitu, satuan waktu, satuan hasil, dan kualitas kerja. Dari hasil penelitian, dimensi satuan waktu yang dinyatakan oleh responden dapat dilihat pada Tabel 5 . 
Tabel 5. Distribusi Fekuensi Jawaban Reponden Dimensi Satuan Waktu

\begin{tabular}{llcr}
\hline No. & Jawaban Responden & Frekuensi & Persentase \\
\hline 1. & Sangat Setuju & 15 & 23.68 \\
2. & Setuju & 28 & 42.11 \\
3. & Ragu-ragu & 23 & 34.21 \\
4. & Tidak Setuju & 0 & 0,00 \\
5. & Sangat Tidak Setuju & 0 & 0,00 \\
\hline & Jum I a h & 66 & 100,00 \\
\hline
\end{tabular}

Sumber : Data diolah, 2019

Dari Tabel 5. terlihat bahwa 15 responden atau 23.68 persen responden yang menyatakan sangat setuju, dan 28 responden atau 42.11 persen yang menyatakan setuju, yang menyatakan tentang dimensi satuan waktu merupakan pembentuk variabel efektivitas kerja pegawai sekretariat daerah Kota Kendari, serta 23 responden atau 34.21 persen yang raguragu. Dimensi waktu merupakan pembentuk variabel efektivitas kerja pegawai di Sekretariat Daerah Kota Kendari.

b. Satuan Hasil, indikatornya adalah, Tingkat perbandingan hasil kerja dengan pekerjaan yang dibebankan dalam jangka waktu teretntu, Tingkat jumlah pekerjaan yang menumpuk, Pekerjaan yang dilaksanakan dalam waktu tertentu. Dari hasil penelitian, dimensi satuan hasil yang dinyatakan oleh responden dapat dilihat pada Tabel 6.

Tabel 6. Distribusi Frekuensi Jawaban Responden Dimensi Satuan Hasil

\begin{tabular}{clcc}
\hline No. & Jawaban Responden & Frekuensi & Persentase \\
1. & Sangat Setuju & 15 & 23.68 \\
2. & Setuju & 28 & 42.15 \\
3. & Ragu-ragu & 23 & 34.21 \\
4. & Tidak Setuju & 0 & 0,00 \\
5. & Sangat Tidak Setuju & 0 & 0,00 \\
& Jum I a h & 66 & 100 \\
\hline
\end{tabular}

Sumber : Data diolah, 2019

Dari Tabel 6, terlihat bahwa 15 responden atau 23.68 persen yang menyatakan sangat setuju dan 28 responden atau 42.15 persen yang menyatakan setuju, bila Satuan Hasil merupakan pembentuk variabel efektivitas kerja pegawai sekretariat daerah Kota Kendari, kemudian 23 responden atau 34.21 persen yang tidak berpendapat tentang satuan hasil merupakan pembentuk variabel efektivitas kerja pegawai sekretariat daerah Kota Kendari.

c. Kualitas kerja,

Dari hasil penelitian, dimensi Kualitas kerja yang dinyatakan oleh responden dapat dilihat pada Tabel 7.

Tabel 7. Distribusi Frekuensi Jawaban Responden Dimensi Kualitas kerja

\begin{tabular}{clcc}
\hline No. & Jawaban Responden & Frekuensi & Persentase \\
\hline 1. & Sangat Setuju & 14 & 22.37 \\
2. & Setuju & 29 & 43.42 \\
3. & Ragu-ragu & 23 & 34.21 \\
4. & Tidak Setuju & 0 & 0,00 \\
5. & Sangat Tidak Setuju & 0 & 0,00 \\
\hline & Jum lah & 66 & 100,00 \\
\hline
\end{tabular}


Dari Tabel 7, terlihat bahwa 14 responden atau 22.37 persen yang menyatakan sangat setuju dan 29 responden atau 43.42 persen yang menyatakan setuju, bila dimensi Kualitas kerja merupakan pembentuk variabel efektivitas kerja pegawai sekretariat daerah Kota Kendari, kemudian 23 responden atau 34.21 persen yang tidak berpendapat tentang pengaruh dimensi kualitas kerja merupakan pembentuk variabel efektivitas kerja pegawai sekretariat daerah Kota Kendari.

\section{B. Pengujian Hipotesis}

Penelitian dilakukan terhadap 66 orang responden dari pegawai di Sekretariat Daerah Kota Kendari. Penelitian ini menurunkan hipotesis statistik sebagai berikut :

$\mathrm{H}_{0} \quad$ : Koordinasi tidak berpengaruh positif terhadap efektivitas kerja pegawai di Sekretariat Daerah Kota Kendari.

$\mathrm{H}_{1} \quad$ : Koordinasi berpengaruh positif terhadap efektivitas kerja pegawai di Sekretariat Daerah Kota Kendari.

1. Hasil pengujian hipotesis dalam penelitian ini sesuai pada lampiran hasil pengujian hipotesis diperoleh model persamaan regresi, yaitu :

$$
\hat{Y}=1.294+0.530 X
$$

Persamaan regresi tersebut menunjukkan bahwa setiap peningkatan variabel koordinasi akan terjadi peningkatan efektivitas kerja pegawai di Sekretariat Daerah Kota Kendari. Sebaliknya efektivitas kerja terjadi jika dilakukan koordinasi dengan baik.

2. Hasil pengujian signifikansi terhadap hipotesis yang dikemukakan menunjukkan bahwa diperoleh hasil $(X)$ bahwa thitung $=6.51898$ lebih besar dari pada nilai tabel $=1.6749$ yang berarti pengaruh tersebut signifikan pada taraf kepercayaan $95 \%(\alpha=0.05)$. Ini menunjukan bahwa $\mathrm{Ho}$ ditolak dan $\mathrm{H}_{1}$ dinyatakan diterima. Hal ini berarti bahwa Koordinasi berpengaruh secara signifikan terhadap efektivitas kerja pegawai di Sekretariat Kota Kendari.

3. Hasil pengujian koefisien Korelasi Spearman-Brown menunjukkan korelasi $X$ dengan $Y$ adalah sebesar 0.532. Nilai hubungan tersebut menunjukan bahwa variabel koordinasi mempunyai hubungan yang relatif sedang terhadap efektivitas kerja di Sekretariat Daerah Kota Kendari.

4. Koefisien determinasi $\left(R^{2}\right)$ adalah sebesar 0.722 . Hal ini menunjukkan bahwa sumbangan variabel koordinasi sebesar 72,20 persen terhadap efektivitas kerja pegawai di Sekretariat Daerah Kota Kendari.

Seperti telah dikemukakan pada pembahasan sebelumnya bahwa hipotesis yang diajukan dalam penelitian ini, secara statistik telah teruji. Namun penelitian ini tidak berhenti pada perhitungan angka-angka saja, karena pada hakekatnya analisis statistik hanya dapat menentukan penerimaan atau penolakan hipotesis penelitian. 
Koordinasi pegawai di Sekretariat Kota Kendari juga telah dilaksanakan karena dengan pembagian kerja batas-batas wewenang, kewajiban dan tanggung jawab akan menjadi jelas, sehingga kekacauan, konflik kewenangan kekuasaan, tumpang-tindih atau kecenderungan menghindari tanggung jawab dapat dihindari. Namun sesuai hasil penelitian menunjukan bahwa masih terdapat berbagai kelemahan-kelemahan, seperti dikemukakan pada hasil pengujian hipotesis. Hipotesanya adalah Koordinasi berpengaruh positif terhadap efektivitas pegawai di sekretariat Kota Kendari. Berdasarkan hasil perhitungan diperoleh thitung sebesar 6.51898 sedangkan tabel sebesar 1.6749 .

Hasil perhitungan tersebut dengan kriteria tolak Ho jika $t_{\text {hitung }}>t_{\text {tabel, }}$ menunjukan bahwa Ho ditolak maka dengan demikian $\mathrm{H}_{1}$ sebagai hipotesis penelitian diterima.

Hal ini berarti koordinasi berpengaruh secara signifikan dan positif terhadap efektivitas kerja pegawai di Sekretariat Daerah Kota Kendari.

Kemudian dari hasil perhitungan tersebut dengan mempergunakan program SPSS versi 15. maka ternyata: Pengaruh langsung $X$ terhadap $Y$ adalah sebesar 0.7220 nilai pengaruh tersebut menunjukan bahwa variabel koordinasi mempunyai pengaruh yang cukup berarti terhadap efektivitas kerja pegawai di sekretariat Kota Kendari. Hal ini berarti besarnya sumbangan Variabel Koordinasi terhadap efektivitas kerja pegawai di Sekretariat Daerah Kota Kendari sebesar 72,20 persen. Sedangkan besarnya hubungan ( $r$ ) variabel koordniasi dengan efektivitas kerja sebesar 0.5320

Kemudian sesuai penaksiran derajad hubungan antar variabel yang dikaji (kriteria Guilford) berada antara $0.40-0.70=$ Hubungan yang cukup berarti.

Hal ini berarti hubungan variabel koordinasi dengan variabel efektivitas kerja pegawai di sekretariat Kota Kendari relatif cukup.

Dengan demikian sesuai hasil penelitian, maka koordinasi aparat berpengaruh secara positif terhadap efektivitas kerja pegawai di Sekretariat Kota Kendari, dengan tingkat hubungan yang relatif cukup. Kemudian kegiatan koordinasi pegawai di sekretariat Kota Kendari sesuai dimensi penelitian mengungkapkan bahwa pembagian kerja seluruh pekerjaan yang harus dilaksanakan untuk mencapai tujuan organisasi. Pembagian kerja (departementalisasi) yaitu pengelompokan pekerjaan yang sesuai dengan latar belakang aparatur, dan adanya semangat kerjasama sesuai dengan fungsi masing-masing bidang, serta komunikasi yang dibangun secara merata dan berkesinambungan dapat disampaikan baik antar bagian dan maupun dalam bagian secara merata, sehingga tidak ada yang salah menafsirkan suatu kebijakan yang telah dilaksanakan, kemudian perencanaan dan perumusan tujuan yang sesuai dengan kebutuhan daripada masing-masing pekerjaan, berdasarkan Perundang-undangan yang berlaku. Hal ini sesuai dengan pendapat Stoner dan Freeman (2012) bahwa koordinasi yang efektif jika komunikasi, hirarki manajemen dan peraturan atau 
prosedur dilakukan dengan baik. Sejalan dengan Westra (2000) menyatakan bahwa koordinasi yang baik dapat diterapkan melalui dimensi komunikasi, pembagian kerja yang jelas, semangat kerja sama, dan prosedur administrasi.

Fenomena pelaksanaan koordinasi sebagai bagian dari fungsi administrasi dalam pelaksanaan fungsi pemerintahan secara internal dalam lingkup pemerintah kota Kendari telah dilaksanakan namun masih ditemui berbagai kendala teknis, seperti : pembagian kerja yang belum merata antara satu staf dengan staf lainnya. Disisi lain, masing-masing bagian atau unit cenderung untuk melaksanakan tupoksi yang ada tanpa melibatkan unit lain, sementara tupoksi tersebut memerlukan kerjasama atau minimal saling tukar informasi. Selain itu faktor semangat kerja sama yang belum terbangun dengan baik. Hal ini disebabkan karena adanya kecenderungan untuk mencari "nama baik" terhadap pimpinan sehingga kadang muncul "ego pribadi".

\section{KESIMPULAN}

Berdasarkan hasil analisis dalam penelitian ini, maka dapat disimpulkan bahwa:

1. Koordinasi berpengaruh secara signifikan terhadap efektivitas Kerja Pegawai di Sekretariat Daerah Kota Kendari. Dimensi-dimensi Pembagian kerja yang jelas, semangat kerja sama, komunikasi, dan perencanaan dan perumusan tujuan diungakpkan bahwa lebih dari lima puluh persen responden menyatakan setuju telah dilaksanakan dengan baik. Dalam penelitian ini juga ditemukan bahwa koordinasi belum dilaksanakan dengan optimal karena faktor Sumber Daya Manusia (SDM) yang relatif masih rendah dan pemanfaatan SDM yang tidak sesuai dengan keahlian dan kemampuannya.

2. Hasil pengujian koefisien Korelasi Spearman-Brown menunjukkan bahwa koordinasi mempunyai sumbangan yang relatif besar terhadap efektivitas kerja di Sekretariat Daerah Kota Kendari. Artinya semakin baik koordinasi dilaksanakan maka efektivitas kerja pegawai semakin tinggi. Dalam penelitian ini juga ditemukan bahwa pelaksanaan tupoksi dari sepuluh bagian dan dua puluh sembilan sub bagian belum dilaksanakan dengan baik.

\section{SARAN}

Berdasarkan uraian pada kesimpulan diatas maka didapat ditetapkan saran-saran sebagai berikut :

Berdasarkan kesimpulan dari hasil penelitian ini, maka saran yang dapat disampaikan adalah:

1. Perlu dilakukan penelitian lebih mendalam mengenai koordinasi pelaksanaan Tupoksi dari masing-masing Asisten, Bagian, Sub Bagian, dan Staf Ahli, terutama koordinasi lintas bagian pada Kantor Sekretariat Daerah lain.

2. Kepada pengambil kebijakan yakni Walikota dan Sekretaris Daerah agar untuk 
meningkatkan efektivitas kerja perlu melakukan pembenahan dan peningkatan kualitas Sumber Daya Manusia dan pemberian tupoksi yang sesuai dengan keahlian dan pengalaman mereka.

\section{DAFTAR PUSTAKA}

Agus dharma, Manajemen Supervisi, PT Raja Grafindo Persada, Jakarta, 2004.

Barnes G.J;(2000), Secrets of Customer Relation ship Management (Rahasia Manajemen Hubungan Pelanggan), Yogyakarta: Penerbit ANDI.

Hasibuan, Malayu S.P. 2016. Manajemen Sumber Daya Manusia. Edisi Revisi. Jakarta: Penerbit PT Bumi Aksara.

Manullang, 2014, Dasar-Dasar Manajemen, Ghalia Indonesia, Jakarta.

Moleong, Lexy, J. 2001. Metodologi Penelitian Kualitatif. Bandung: PT. Remaja Rosda Karya.

Richard L. Daft. 2014. Era Baru Manajemen (New Era of Management). Edisi 9 Buki 1. Jakarta. Penerbit Salemba Empat.

Simamora, Henry (2015). Manajemen Sumber Daya Manusia. Yogyakarta: STIEY

Simon, Herbert, A. 1982. Administrative Behavior. Terjemahan ST Dianjung. Bina Aksara. Jakarta.

Stoner dan Freeman, 2012. Manajemen. Surabaya.Gramedia

Taliziduhu Ndraha. (2012). Budaya Organisasi. Jakarta: Rineka Cipta.

Terry, George R. 2010. Dasar-Dasar Manajemen. Cetakan kesebelas. Jakarta: Bumi Aksara.

Tjokrowinoto, Moelyarto. 1996. Pembangunan Dilema dan Tantangan. Cetakan Pertama, Jakarta : Pustaka Pelajar (Anggota IKAPI).

Peraturan Pemerintah Kota Kendari Nomor 5 Tahun 2016 tentang Pembentukan dan Susunan Perangkat Daerah Kota Kendari.

Westra, 2000, "Beberapa Masalah Dalam Hubungan Kerja Kemanusiaan", BPA UGM, Jogjakarta. 